\title{
Assessing the Teaching Practice Processes of Preservice Teachers and Their Competencies of Mathematics Teaching within the Scope of Teaching Practice Course ${ }^{i}$
}

\author{
Zeynep Doğan
}

Department of Primary Education, Yildiz Technical University, Istanbul, Turkey

Copyright $\bigcirc 2019$ by authors, all rights reserved. Authors agree that this article remains permanently open access under the terms of the Creative Commons Attribution License 4.0 International License

\begin{abstract}
The aim of this study is to examine the application process of preservice primary school teachers in primary schools within the scope of teaching practice course. In addition, the aim of this study is to evaluate the preservice teachers' mathematics teaching competencies by the practice teachers in their schools. For the purpose of the study, semi-structured interview technique was used from qualitative research methods. The sample of the study was composed of 17 primary teachers assigned as practice teachers in the school they study. The data were collected through semi-structured interviews with these teachers. As a data collection Tool, the interview form prepared by the researcher, which includes questions about the application process and Mathematics teaching competencies of the pre-service teachers who continue to practice throughout the semester was used. According to the findings, although the level of professional knowledge of the preservice teachers was generally good, it was not seen that they were sufficient in professional skills because of being inexperienced. The situations were the same specifically in the level of professional knowledge and skills in mathematics teaching. It was stated that pre-service teachers were generally willing to come prepared for the course and to prepare in cooperation with the teacher. It was stated that pre-service teachers had a positive relationship with students in the classroom, but discipline problems could arise when students felt it especially when the preservice teachers were unprepared.
\end{abstract}

Keywords Mathematics Teaching, Primary Teachers, Pre-service Teachers, Teaching Practice

\section{Introduction}

Teaching practice is undoubtedly one of the most important factors in the pre-service teacher training. And it is a pre-study by senior students on the way to becoming a teacher. Therefore, "teaching practice", which was included in the primary school teaching program with the restructuring of faculties of Education in 1998, has become a fundamental part of the education program as an implementation made by pre-service teachers in schools within the framework of faculty-school cooperation. This practice is an important practice that enables theoretical knowledge to be transformed into practice. This practice aims to develop teacher competencies by enabling them to teach in different classes at the school, to understand the curriculum of the field, to evaluate textbooks, to make measurement and evaluation, to share the experiences of the teaching practice with their friends and their professors [1-3].

The general aim of the teaching practices foreseen by the Faculty-school cooperation is to contribute to their individual and professional development by providing pre-service teachers with the opportunity to use the knowledge, skills, attitudes, values and habits gained in the courses of field culture, general culture and professional knowledge effectively and sufficiently in the education life [4]. According to Gokce and Demirhan [5], the most important function of teaching practice in teacher training programs is to introduce the teaching profession and, in this respect, that the practice teachers contribute to the professional development of pre-service teachers at the schools. The teacher has to constantly improve himself / herself by starting from the pre-service training in the face of rapidly changing and evolving conditions, with the responsibility of educating the individuals in a qualified manner. A teacher who is equipped with the knowledge, skills and attitudes required by the teaching profession, has also gained various experiences with activity practices in the real school environment. The experiences of pre-service teachers in practice schools, guided by the practice teachers, have a very important place in the life. To the degree that the practice teachers in schools can reflect 
their experiences to pre-service teachers, they can be effective and efficient [5]. In the study of teaching practice done by Kete and Sellers [6] it is stated that the practice teacher and the professors giving the practicum course have an impact on the adaptation to the profession, acquiring the occupational concepts, the activities and practices in the classroom and pre-service teachers dealing with occupational problems, however, there is inconsistency in the reflection of this effect on the behavior of pre-service teachers. In addition, problems such as contradictory expectations between the practice teacher and the practicum course lecturer, role conflicts, method differences regarding the teaching of the lessons, the inability to decide together and discussing the practice superficially have been determined in teaching practices [7-10].

It is seen that the process of teaching practice is influenced by the harmony between the practicum instructor, the practice teacher at the school and pre-service teacher. The lecturer who teaches the theoretical perspective of the practicum course can experience some problems in communicating with the practice teacher at school. Although the instructor is following the process of pre-service teacher in the practice school, the practice teachers controlling their views, their thoughts and their expectations related to the process, will affect the practice process positively. The aim of this study is to examine the thoughts, the views and the expectations of the practice teachers about the different variables such as the teaching competency of pre-service teachers who continue to practice within the scope of the teaching practices course, their attitudes and approaches during the process of the practice, the effects of the practice on the classroom environment and the effectiveness of the practice. In the study, it was found that the evaluation of these variables in detail in line with the teaching skills of pre-service teachers was appropriate for the purpose of the study.

\section{Method}

\subsection{Research Sample}

The sample of the research was composed of 17 primary teachers who were assigned as practice teachers in the school they study. These teachers participated in the study considering the principle of volunteerism.

\subsection{Data Collection Instrument}

Within the scope of the research, semi-structured interview forms were created to determine the views of practice teachers on the process. In these forms, there were questions about the teaching practice carried out by the pre-service primary school teachers during the semester. These questions were first formed by the researcher, and then the opinions of 4 related field experts were asked. The final version of the questions was given after the necessary corrections. In the final form, there were 17 questions under the category of teacher competencies, the approaches of the pre-service teachers, the effects on the classroom environment, the evaluation of the teaching practice studies.

\subsection{Data Collection and Analysis of Data}

Semi-structured interviews with the practice teachers were conducted using the prepared interview form. Teachers were informed that all kinds of confidentiality would be obeyed in the interviews. Interviews were conducted face-to-face and recorded for the analysis.

In the analysis of the data, the recorded sound was first transcribed. Then, the answers given to each question were analyzed in detail and the similar answers were coded accordingly.

\section{Findings}

\subsection{Findings on the Dimension of 'Teacher Competencies'}

In the interviews, first of all, the practice teachers were asked questions about teacher competencies. They were asked to what extent the pre-service teachers provided teacher qualifications within the scope of field knowledge and legislative information. In the answers given to the question, it was stated that the pre-service teachers were sufficient in the general field knowledge, but there were deficiencies in specific field education. That is, according to the practice teachers, the pre-service teachers had sufficient knowledge about the subject they were teaching but they were inadequate in transferring their knowledge. They had difficulty in expressing the topics according to the level of the students during the teaching process. Also, it was stated that pre-service teachers were often inadequate in classroom management. The reason for the situation was that teachers were inexperienced, unable to adjust their voice tones, unable to link subjects to everyday life, not seen as a teacher by the students, and having crowded classes. T1 said to express her ideas on the issue; 'Our problem is that pre-service teachers have no chance to reach all children because it is the first time for them to experience teaching. Classes are crowded, so they cannot communicate with all students. In general, the classical lecture type is being used. Sometimes, they let children play with the materials. Only 10-15 children can play, but the others cannot play because the classes are very crowded. This is not mistake made by pre-service teachers. '. T6 said, 'They know the knowledge of the methods and the techniques but there are insufficiencies in their practices. The education they receive during their undergraduate 
program is sufficient for recognition and knowledge of the profession, but insufficient for the achievement of acquisitions with the students. They are inadequate to come prepared for class, to plan and to create materials. They also make general evaluation, but there are deficiencies in process evaluations. They are inadequate to have full knowledge of the subject and to create activities for the students at different levels. Their communication processes are changing according to children. Also, there are lack of information on personal rights, formal business and transactions about the legislation procedures. Additionally, they are insufficient in classroom management, time management and arranging the tones of voice'.

Similarly, when asked about mathematics related field and field education knowledge, it was stated that the field knowledge was sufficient but the field education information was not enough. Since the teaching process mentioned here is for elementary school level, there is no need for the mathematical knowledge that the pre-service teachers should have at the very high level at the point of field knowledge. It was also stated that pre-service teachers had sufficient knowledge about basic mathematics themes. Although the mathematics issues at elementary level were at the basic level, the main point here was to simplify these issues based on the level of the students. The practice teachers also expressed that they felt the deficiency in the pre-service teachers, especially in their teaching of mathematics. the statements of T7 was given as an example about this problem; 'In the process of solving some problems, I witnessed that the pre-service teacher solved the problem with an equation. Elementary school student can't solve the problem with equations. The pre-service teachers have to explain the problems as if the students know nothing'.

\subsection{Findings on the Dimension of 'Approaches of Pre-service Teachers'}

One of the first questions under this dimension was "Did pre-service teachers consult you on teaching issues?". The majority of the teachers answered "yes" to this question. In other words, the pre-service teachers mostly did preliminary studies on the subject/subjects to be discussed in that week and they consulted the practice teachers for these preliminary studies. T4 stated her thoughts related to the dimension; 'Absolutely. They come all the time. They even come for presentations that they will make at University. They come and ask how to explain a subject of a lesson'. The teacher T2 who stated that the pre-service teachers did not consult him about how to teach the subjects, said, "They do not ask. They are just coming to ask the theme of the week".

Another question was, "Are they consulted on how to teach mathematics subjects?" and most of them stated that pre-service teachers consulted them about the teaching method. T10 said, 'Yes, they asked how to solve some problems and how to do them in accordance with the level of the students rather than the equation'. The teacher T11, who stated that she was not consulted, said, "No. I just gave them the themes. They did not ask me how to teach them. I had to intervene while she was teaching in the course hour. For example, multiplication and division topics have been introduced by our pre-service teacher. She did not ask me anything. These issues are difficult for primary school students. On top of that I had to interrupt the pre-service teacher in the classroom' in order to explain the problematic situation.

The majority of teachers stated that they were generally enthusiastic about whether teachers were willing to do internships, but there were also those who were reluctant. The practice teacher T7 said in order to state how willingly the pre-service was, "He was very willing. He was asking me if I could give him the next class hour. He had confidence in himself. Especially in the last 1-2 months it had been a big change on him. In this process, I think it is important to how to treat the pre-service teachers. If deficiencies are said, effectiveness cannot be provided. I was always constructive and contributing to him with my recommendations". Some teachers stated that the pre-service teachers saw the implementation process as a process that needed to be completed as soon as possible because the pre-service teachers would take the teaching exam in a few months. Similarly, some teachers stated that there were teachers who only come to sign.

\subsection{Findings about the Dimension of "the Effects on Classroom Environment"}

When teachers were asked whether the process of implementation was disruptive or beneficial to the classroom environment, some of them stated that they were disrupted and some of them expressed that it was a useful process for them. In addition to this, the practice teacher T4 said, 'No, it was useful. Children liked to see different teachers. But the students chattered because the pre-service teacher was lack of the authority in the class. Children had great time with the pre-service teacher. I saw that the students listened to the pre-service teacher carefully'. The practice teacher T7 said, 'He was disappointed for the first couple of weeks. The students were shocked when they saw a new teacher. The pre-service teacher wanted to cuddle them. I introduced the pre-service teachers as teachers to the students. I emphasized they are the practice teachers of the classroom so that the students accepted them as their practice teachers'. On the other hand, the practice teacher T1 said, 'The classroom was distracted. Generally, I did not give a new topic to the pre-service teacher. I wanted him to review the same theme. Because the pre-service teacher was unexperienced. It was very difficult to change the misconception if the children learned the first thing wrong'. Also, the practice teacher T12 said, 'Of course the daily plan changed. The flow of the lesson was affected. 
Sometimes, we needed to teach a new theme but in order to contribute to the pre-service teacher, we changed the plan and gave him the opportunity to review the theme'.

When the practice teachers were asked how the students in the class were about the attitude towards the pre-service teachers, it was stated that there was a positive relationship between the pre-service teachers and the students in most cases. The practice teacher T2 emphasized the attitudes of children towards the pre-service teachers with these statements; 'The students loved the pre-service teachers. Spending all the school hours with same teacher was boring and therefore they were welcoming the new teachers'. However, in some cases it was stated that brother and sister relationship may be more relevant than teacher-student relationship. In particular, it was stated that students were not able to perceive them as teachers in situations such as not being able to use the tone of voice, not being able to provide classroom Management, giving the sense of lack of having full knowledge of the subject. In these cases, it was stated that discipline problems were the main issue in the classroom. However, it was emphasized that these situations were out of the question for pre-service teachers who were prepared for the course and who adopted to the teaching profession. The practice teacher T13 described the first impression of students with these statements; 'First, the students thought that the pre-service teacher was a class assistant. When she started to teach them, they understood that she was also a teacher. Then, they respect to her in the teacher-student relations.

When asked about how pre-service teachers ' attitude towards students, most of the practice teachers responded that they were warm and sincere. The practice teacher T1 said 'He was good. There was an exceptional student in my classroom. The pre-service teachers took care of all the students without making any discrimination' in order to explain her thoughts about the pre-service teachers' attitudes. Also, the practice teacher T11 said, 'The students liked him more. I thought that it was because of loving being a teacher'. Additionally, the practice teacher T13 said, 'She was good. She even prepared a game like a wheel. She was playing at recess. Every week, she was coming with another material'. Only one teacher stated that her pre-service teacher held herself at a distance. The practice teacher said, "'She is a little distant. She may not feel because of her character'.

\subsection{Findings on 'the Evaluation of the Teaching Practice Works'}

The question of "If you compare the teaching practice processes in your own pre-service teacher years you're your current teaching, what kind of difference do you make?" was asked to the practice teachers, the majority of teachers stated that the processes in their own time were more efficient and useful. As one of the reasons for this, it was stated that the time of internship was more when they were pre-service teachers. At those times, it was also stated that the teaching practices were applied more strictly. In addition, in their own period, both in the practice of teaching process in primary schools and in the theoretical course of teaching practice at the university, the faculty members were following the pre-service teachers more closely. In addition to this, the practice teacher said, 'Because our coordinators constantly checked us, we had no chance of absenteeism or coming to school unprepared. Our works were evaluated in weekly reports. Our practice teacher and our professor in our university were in communication with each other and the themes we missed were eliminated through collaborative work'. The practice teacher $\mathrm{T} 7$ said, 'In the first semester, we observed the classroom. In the second semester, we practiced teaching in the classroom. In the following year, we practiced teaching of subspecialty of our professions. We also had an administration internship. We got information about the correspondence, filing etc. with the assistant manager and officer'. In addition, the practice teacher T8 said, 'We went to teaching practice for a year. We were going for five days a week. We observed for a month. We just listened. And then we started teaching. We were in charge of administration for one day a week. But now it is not like in the past. They have no knowledge of the functioning of the school. They just get in and out of the classroom. In the last period of our internship, we went to the multi-age classroom for a month". On the other hand, some teachers have stated that current practices are more efficient and useful. The practice teacher T11 said, 'This system is more efficient. In the past, we were going to observe the classroom when we were at the first year of undergraduate program. Now, pre-service teachers start the observation of the class in the 3rd year of university and they start teaching practice in the 4th year at university. Now, they're making more conscious observations in the classroom. We reflected our observations in the first grade only at the end of the fourth grade. Time was passing. But the pre-service teachers are observing. I think that if the pre-service teachers are enthusiastic, they will be more productive for the students with the new knowledge gained from the courses at university'. Apart from, the practice teacher T13 said, 'In our time, there was no fear of grade. There was no such thing as the grades being processed on the ministry's system. But now the grades are processed on the ministry's system. Therefore, the pre-service teachers are more serious'.

Pre-service teachers were asked whether teaching practice works of the pre-service teachers were useful, all of the teachers said that they found them helpful. The practice teacher T4 said, 'I find them useful. It is good for the pre-service teachers to see the students as soon as possible. When I was in college, I did not know that teachers were on duty at school, that the papers were supposed to sign, and how to establish a dialogue with children. I learned everything in the teaching practice course'. Additionally, the practice teacher T5 said, 'Of course! It must be a master apprentice relationship. I'm a 
master. The pre-service teacher will come to me and benefit from my knowledge'. However, for some reasons, it was stated that there might also be negativity. In these practices, pre-service teachers went to practice 1 day a week for 14 weeks. Teachers often did not find this time enough. Besides, in some schools, pre-service teachers went to different classes every week so that they could see different teachers and the levels of grades. Some teachers stated that this situation also caused problems. In this way, both the students and the teachers stated that they also experienced the adaptation problem related to the next pre-service teacher. The practice teacher T1 said, 'It's not efficient to take classes in different grades every week. The pre-service teacher cannot adapt to the class. Also, we start thinking of the next pre-service teacher. For example, the pre-service teacher should stay in the same class for four weeks. Then, another pre-service teacher takes turn. Thus, the pre-service teacher gains experience at every class level'.

When asked what could be done to make internship practices more efficient and beneficial, teachers expressed a variety of opinions. One of the opinions expressed intensively was that pre-service teachers should attend the same class with the same teacher for several weeks instead of attending a different class each week. Also, increasing the practicum time is among the answers given intensively. Based on the idea mentioned, the practice teacher T12 said, 'The pre-service teachers visited for 14 weeks. They need to come more. Because they start getting used to the class and changing the teaching styles according to the children'. In addition, it was stated that it was also useful and important to have enough experience at different class levels $\left(1^{\text {st }}, 2^{\text {nd }}, 3^{\text {rd }}\right.$ and $4^{\text {th }}$ grade $)$. In other words, the pre-service teacher should be sent to a different class each week to prevent adaptation problem. Also, they should not be sent to the same class in order to provide the opportunity of gaining various experience from different classes. In addition, it was stated that the more efficient process is related to the advisors at the University and that the advisors should take part in the process more actively. It was important for counsellors at the university to communicate closely with both practice teachers and pre-service teachers. It was stated that the evaluation process should be carried out carefully based on observations and the performance of the pre-service teacher. If the pre-service teacher is absent or unprepared, it was expected that it must be considered in the evaluation process. It was stated that evaluation should be made in order to incorporate unsuccessful pre-service teachers into the practice processes in the following semesters. On the other hand, the practice teacher T6 stated that pre-service teachers should not only come to primary schools as part of the teaching practice course but also as part of the teaching courses at the University.

In the practice process, teachers answered a variety of questions when asked what the pre-service teachers needed most about teaching mathematics. One of them is about time management in the classroom. It was stated that while pre-service teachers were teaching mathematics, situations such as having extra time or not having enough time frequently arose. In particular, it was stated that disciplinary problems arose when the student was aware of the remaining time. Therefore, the pre-service teachers must gain experience about timing and take the time management issues into account while creating the course content. The practice teacher T5 mentioned her thoughts with these statements; 'Their biggest shortcomings are lack of knowledge-experience. Teaching is learned by trying. The education in college is different. The pre-service teachers need experience. What they learned in theory is very different from practice. It is especially important to give pre-service teachers to the experienced teachers who worked in the multi-age class and worked at the Eastern part of the country. The primary school teachers are like an aspirin. That is, they should solve the problem. When you go to the village, you will be a doctor, a judge, a prosecutor, a teacher, a brother and a sister. That is the teaching profession. It was also stated that pre-service teachers should receive support from experienced teachers about Mathematics and other disciplines related to teaching. Thus, it was stated that they were able to understand the way children think and how they could get down to their level. It was stated that it was important to update the curricula in universities in order to keep pace with today's developments. In addition to this, the practice teacher T11 said, 'Education programs at the University need to be updated differently. I think the contents of the curriculum are inadequate. As a teacher, we start to struggle with the questions of elementary school students. The perceptions of the students are incredibly clear. It is hard to keep up with them. We are constantly asking questions on interesting topics and honestly we are unable to answer some of the questions. Therefore, courses on curiosity and questioning should be added in teacher training programs'.

\section{Conclusions and Discussion}

Teaching practice processes can be considered as the most important stage of teacher education for a pre-service teacher. As emphasized by Ozkan et al. [11], the knowledge obtained by pre-service teachers can only gain in value by implementing the activities. In the study, the processes carried out by the pre-service teachers within the scope of teaching practice were examined. At the same time, it was aimed to examine the mathematics teaching competences of the pre-service teachers because the primary school students who were in the process of concrete operations could have difficulties in learning the mathematics lessons containing abstract concepts. In the study, the practice teachers who were working at the public school as primary school teachers were interviewed and their views were examined.

According to the findings obtained from the research, 
the practice teachers generally find the field knowledge of the pre-service teachers sufficient. As a reason for this, it was stated that pre-service teachers were well trained in terms of the field knowledge and the subjects at the elementary level were easy. However, it was stated that there were some shortcomings of pre-service teachers in terms of the field education knowledge. Improving the teaching skills of pre-service teachers was considered as the main objective of teaching practice [12]. Although the pre-service teachers had information about the subject they were going to teach, it was stated that they had deficiencies in transferring this information to primary school students. This is because, some pre-service teachers came unprepared for the classes. However, according to the most defended opinion, it was directly related to the experience that the themes were taught by simplifying them to the level of primary school students. It was stated that this situation emerged as a result of the lack of teaching experience of the pre-service teachers. Therefore, it turned out that the pre-service teachers needed to implement activities in order to get more experience in the teaching practices as much as possible. Also, some teachers stated that only the teaching practice course needed to be in $4^{\text {th }}$ year of the undergraduate program of the primary school teaching. In this respect, it was indicated that the pre-service teachers were able to gain a healthier and productive teaching experience by coming to the practice school every day of the week rather than just one day a week. On the other hand, given the basic functions of the faculties of education, it was thought that the pre-service teachers needed to be provided with the knowledge of field education. When the current primary school teaching program was examined, it was observed that the courses for teaching were mostly given in the third grade and there was no other activity for teaching. At this point, it could be considered that the implementation of a teaching course plan spread to all undergraduate courses in order to achieve the gains for the teaching profession.

According to the observations of the man teachers, another general situation about the pre-service teachers was that they were inadequate in the classroom management. It was stated that the lack of experience of pre-service teachers led to the difficulties in the classroom environment. Students who realized that pre-service teachers were inexperienced could not fully perceive them as a teacher, which could lead to disciplinary problems in the classroom. It was understood that the pre-service teachers were not able to adjust the distance between the students. The fact that students considered pre-service teachers as an elder brother/sister was also cited as the reasons for this situation. It was thought that the approach of the practice teacher and the pre-service teacher plays a decisive role in this regard. It was thought that if the practice teacher introduced the pre-service teacher as a teacher and supported this idea with his / her words, the pre-service teacher would have performed a more effective classroom management. Similarly, the pre-service teacher could perform a more effective classroom management by coming prepared for the lesson and feeling that he / she was a teacher with his / her words and behaviors. At the same time, there is a situation about the effectiveness of the classroom management course which is given theoretically in the Faculty of Education. In this context, it can be seen that it is important to prepare a new course plan in which classroom management courses can be applied in a wide perspective. In the process of teaching practice, the communication of pre-service teachers with the practice teacher was examined and it was observed that there was a positive communication process. The practice teachers stated that the pre-service teachers were communicating with themselves about the subject by asking how to explain the topic and in what way they could perform a more effective teaching. Similarly, they expressed that the pre-service teachers asked questions about mathematics themes in order to benefit from the experience of the practice teachers. In this respect, they have expressed that the vast majority of pre-service teachers were willing to participate in the teaching practice process. However, it was also pointed out that some pre-service teachers were reluctant to come to practice and to teach lectures.

According to the views of the teachers, the processes of teaching practice affected the flow of the course inevitably. Most of the teachers stated that these processes adversely affected their classroom flows, but somehow they were trying to remove them. Contrary to this view, some teachers stated that the implementation process was a positive contribution to their classroom environment.

The majority of teachers evaluating current teaching practice processes pointed out that the teaching practice processes in the past were more beneficial and productive. They stated that they carried out the teaching practices in a much longer period, that they continued constantly, that the lecturer of practicum course was following them more frequently and that they taught in the same class for one year or one semester instead of changing the class frequently. Teaching practices have a content that change from one year to another and from a university to another. In this context, it is important to develop a lesson plan for a more useful teaching practice process and to evaluate the good and bad aspects of these practices in detail. The practice teachers who evaluated the teaching practices in general indicated that these processes were always beneficial to the pre-service teachers, although some problems were mentioned. Because what pre-service teachers need most is to gain experience in the classroom environment, and even if there are deficiencies, the pre-service teachers are required to gain experience in these processes.

Teachers expressed their opinions on what could be done in order to make the practice processes more efficient. Extending the practice process as much as possible was one of the most frequently mentioned views. 
This finding shows a similarity to the findings of the studies of Ozkan et al. [11] and Azar [13]. In addition, it was also inefficient for a pre-service teacher to perform the practice in different classes each week with different practice teachers. Because it is very important to adapt to the teaching and the students in the process of implementation. Instead of 1 day a week, a couple of days a week at least was considered useful for the implementation process. In this way, the pre-service teacher was able to integrate with the students and the practice teacher. In addition, it is stated that it will be more useful to gain experience about how to continue the same course the next day after the end of a course. Besides, it is stated that the lecturer of the practicum course in the university has to come to the practice school personally, observe and evaluate the pre-service teacher while teaching the class.

In mathematics teaching, it is stated that it is important for pre-service teachers to learn to manage time effectively. The pre-service teacher should come to the lesson and prepare the course content as much as possible about the topic, so that he/she can use the time in the most effective way. This is necessary in order to avoid situations such as lack of time or having extra time to fill the course. It is thought that this can be achieved more easily when the pre-service teachers are given to the experienced teachers as much as possible in the teaching practice processes. In general, when the numbers of observations and practices are increased for the pre-service teachers, their teaching skills are improved.

\section{REFERENCES}

[1] YÖK (Yüksek Öğretim Kurulu) (1998). Fakülte-Okul İş birliği YÖK-Dünya Bankası Milli Eğitimi Geliştirme Projesi Hizmet Öncesi Öğretmen Eğitimi, Ankara.

[2] Paker, T. (2008). Öğretmenlik Uygulamasında Öğretmen Adaylarının Uygulama Öğretmeni ve Uygulama Öğretim
Elemanının Yönlendirmesiyle İlgili Karşılaştıkları Sorunlar. Pamukkale Üniversitesi Eğitim Fakültesi Dergisi (1) 23. Say1 132.

[3] Özkılıç, R., Bilgin, A., Kartal, H. (2008). Öğretmenlik Uygulaması Dersinin Öğretmen Adaylarının Görüşlerine Göre Değerlendirilmesi. İlköğretim Online, 7(3), 726-737, 2008.

[4] Hacıŏlu, F. \& Alkan, C. (1995). Öğretmenlik Uygulamaları Öğretim Teknolojisi, İstanbul: Alkım Yayınevi.

[5] Gökçe, E. \& Demirhan, C. (2005). Öğretmen adaylarının ve ilköğretim okullarında görev yapan uygulama öğretmenlerinin öğretmenlik uygulaması etkinliklerine ilişkin görüşleri. Ankara Üniversitesi Eğitim Bilimleri Fakültesi Dergisi. 38(1): 43-71.

[6] Kettle, B. \& Sellars, N. (1996). The development of student teachers' practical theory of teaching. Teaching \& Teacher Education, 12, 1- 24.

[7] Duffy, P. (1987). Student perceptions of tutor expectations for school-based teaching practice. European Journal of Teacher Education, 10, 261- 268.

[8] Borko, H. \& Mayfield, V. (1995). The roles of the cooperating teacher and university supervisor in learning to teach. Teaching \& Teacher Education, 11, 501-518.

[9] Haggarty, L. (1995). The use of content analysis to explore conversations between school teacher mentors and student teachers. British Educational Research Journal, 21, 183197.

[10] Paker, T. (2000) Teaching practice from student teachers' perspective. Çukurova University, Journal of Social Sciences, 6(6), 111-118.

[11] Özkan, H. H., Albayrak, M., ve Berber, K. (2005). Öğretmen Adaylarının İlköğretim Okullarında Yaptıkları Öğretmenlik Uygulamasının Yetişmelerindeki Rolü. Milli Eğitim Dergisi, 33,168 .

[12] Topkaya E. Z. ve Yalın M., (2004). Uygulama Öğretmenliğine İlişkin Tutum Ölçeği Geliştirilmesi. Eğitimde Kuram ve Uygulama, 1(1-2), 14-24.

[13] Azar, A. (2003). Okul Deneyimi ve Öğretmenlik Uygulaması Derslerine İlişkin Görüşlerin Yansımaları. Milli Eğitim Dergisi,159, 1-10. 